\title{
A Spatial Analysis of Child Labour Utilization in the Tourism Industry of the Eastern Tourism Region of Sri Lanka: Issues and Challenges
}

\author{
Hettiarachchi Han (PhD) \\ Thennakoon TMSPK (PhD) \\ Department of Geography, University of Sri Jayewardenepura, Sri Lanka
}

Doi:10.19044/esj.2019.v15n7p11

URL:http://dx.doi.org/10.19044/esj.2019.v15n7p11

\begin{abstract}
Tourism is the world's leading and fastest growing industry which generates many positive impacts on the destinations. It is also considered as a root cause of generating different socio-cultural problems. Employing of child labor in different tourism related activities is a prominent issue and it has now become a common jeopardy and a public debate, especially among social scientists. Therefore, an incessant attention has been given to study the different facets of this issue. This background is common in the Sri Lankan tourism industry too. The main objective of this research was to study the issues and challenges of utilizing child labor in the tourism industry of the Eastern Tourism Region of Sri Lanka. After a preliminary survey, Ampara, Trincomalee and Batticaloa districts were selected as the study area. The judgment and purposive sampling methods were used to select the sample and the total sample of this research was 190, which comprised of 140 child workers and 50 tourism related establishments. Both quantitative and qualitative methods were employed to collect data. The data was analyzed applying qualitative and quantitative analytical methods. The overall findings of the study are discussed under several sub headings including the overall nature of the child labour utilization with main facets such as the existing nature and types of work, the place of work, salaries and wages, different problems faced by child workers and the existing issues and challenges. As per the general findings of the research the child workers of the study area have been employed in both formal and informal sectors of the tourism industry. The issues related to child labour utilization are in two main forms viz. the different issues and challenges faced by child labourers and the business community of the study area.
\end{abstract}

Keywords: Tourism Industry, Eastern Tourism Region, Child Labour, Labour Utilization, Issues and Challenges 


\section{Introduction}

Tourism is the world's leading and fastest growing industry which generates millions of employment opportunities. It has been identified as a significant strategy in the process of socio economic development of different countries of the world. As a result of that, a paramount attention has been given to promote it as a mechanism to accrue different benefits. Though, tourism has various social, economic, cultural, psychological and environmental impacts, it is also considered as a root cause of generating different socio-cultural problems. Among these diverse social problems, employing of child labor in different tourism related activities is a prominent issue. This problem is more common in developing countries. Due to various reasons, employing child labour in tourism has become a social issue in these countries. They have being employed in extremely hard working conditions without even being paid fairly, protection for their long strained working hours sometimes under very unhealthy and dangerous conditions. The common type of employments in which the child labour is being employed are bellboys, waiters or waitresses, kitchen helpers, assistants in tourism related construction sites, janitors, watchers or caretakers of tourist sites including adventure parks and other attractions, helpers in recreational activities, sellers of different items in and around tourist attractions or waysides and operatives in communications and internet cafes. Employing children in such capacities is a common jeopardy which becomes a public debate especially among social scientists.

Use of child labour in the tourism industry is an international contemporary social problem. Therefore, an incessant attention has been given to study the different facets of this issue. As a result of these unceasing efforts, policies and legislations have now being formulated and implemented in different countries with the main aim of eradicating the different problems associated with child labor utilization. At the same time, reduction of negative impacts including the child labour utilization is important because it is considered as a key indicator of the sustainable development of tourism industry.

Over the last few years, the tourism industry of Sri Lanka has become one of the main activities in the economic agenda of the country. This is due to different reasons such as the generation of more employment opportunities, high level of contribution to the Gross Domestic Production (GDP), peripheral regional development etc. Even though, many impacts are positive and significant, there are different problems which are considered as negative and perilous. Employing of child labour is more common among these noticeable negative impacts. Due to different reasons, attention has now been paid to alleviate the diverse issues of child labour utilization in tourism. Since, a study which focuses on issues and challenges of utilizing child labor in the tourism industry and the finding of the study will create a sound platform to mitigate, 
manage and tackle this multipronged issue. In this way, it can be concluded that this research which focus the different issues and challenges of employing child labor in the tourism industry of the Eastern Tourism Region is timely and significant.

\section{Literature Review}

According to the United Nations (2018) around 218 million children throughout the world have been employed to work full-time in different sectors. In absolute terms, almost a half of child labourers (72.1 million) are to be found in Africa; 62.1 million in Asia and the Pacific; 10.7 million in the Americas; 1.2 million in the Arab States and 5.5 million in Europe and Central Asia. Recently, there has been a renewed universal concern about the presence and impact of child labor from international and national organizations, politicians, activists and academics alike. Research on the utilizing child labor in industrial sector began to expand rapidly during the past decade (20002010). This rapid expansion and growth is also reflected in the research in tourism and hospitality sector and attracted the attention of a growing number of researchers and policy makers.

The study on the role of employers' associations in child labor elimination of the International Labour Organization (2007) reveals that, millions of children in the world have been trapped in a world of work. This study further reveals that, a majority of them are at risk from hazardous and exploitative labour and denied their basic and fundamental right to education, health and childhood. This research critically examines the reasons why children work, the risks to a child working in the tourism sector, the role of the tourism industry employers and associations to mitigate this problem and the initiatives undertaken by the International Labour Organization (ILO), the World Tourism Organization (WTO) and the Government of India to address the problem (ILO, 2007). According to the ILO (2012) the total number of child workers employed in the tourism sector is increasing even though it is a criminal act and forbidden by law.

Child labour refers to the employment of children in any work that deprives children of their childhood, interferes with their rights to attend regular school, and that it is mentally, physically, socially or morally dangerous and harmful (ILO, 2012). As defined by the ILO (1983), "child labour includes children prematurely leading adult life, working long hours for low wages under conditions damaging to their health and to their physical and mental development, sometimes separated from their families, frequently deprived of meaningful education and training opportunities that would open for them to a better future.” As cited by Hagedoorn (2013) the ILO and other international organizations consider child labour as work that deprives 
children of their childhood, their potential and dignity, and that is harmful to their physical and mental development.

As stated by Luwaga (2005) child labour is taking place all over the world particularly in low income countries and they are being employed in different sectors such as agriculture, tourism, manufacturing, fishing, construction, domestic services, street vending and other formal and informal sectors. They are working in very poor and dangerous conditions even without basic protection. As cited by Nagar and Roy (2016) Lavison and Murray (2005) have reported that child labour involves in many different forms of works with risks and hazards and they are vulnerable to physical pain and injuries particularly they are exposed to health hazards. As they further cited Fasih (2007) has stated that child labour creates unskilled and uneducated labour which affects a country's development and economy. Nagar and Roy (2016) further cited the work of Mapaure (2009) and elaborated different reasons which make children to work in different sectors. According to him, the main causes that induce children to work are poverty and the survival of their families.

Rao (2008) analyses the dimensions of child labour in India and the broad trends and multidimensional approaches to the problem of child labour. He further discusses the nature, magnitude, working conditions, causes and consequences and the position of child labor engaged in different industries in different parts of the country. He also reveals and analyses the socio-economic characteristics of child labour, their levels of earning, standards of living and impact on household income. Rao (2008) further states that child labor is a complex issue in the tourism industry in India. According to him, the workers between 6-8 years, have to face many difficulties including hunger, humiliation and physical and sexual abuse which ultimately lead them towards poverty, unemployment and illiteracy. Kanbargi (1991) in his book titled Child Labour in the Indian Sub-continent analyses the demographic trends of child labour and its relation with fertility, literacy and education. Further, various aspects of migrant child workers have been discussed and suggested strategies to eliminate the problem of child labour by Kannan (2007). He discusses the determinants and correlation of child labor in the context of liberalization and globalization. As cited by Sharma, Kukreja and Sharma (2012) Rajendran (1998) has conducted a pilot study on the migrant children working in the hotels and restaurants of Dindigul district of Tamil Nadu and revealed the nature and the types of work they are doing. Das and Sing (2016) in their study of socio economic condition of child labour working in hotel industry of Barak valley in Assam highlighted that the percentage contribution of child labour for the tourism industry of Assam of India was 5.3\%. They further reveal that the sectorial contribution of children to the hotel and tourism sector together was $7.76 \%$. 
Hagedoorn (2013) cited in his study that very little research has been done on child labour in tourism in the past. Further he cited the work of Plüss (1999) who had conducted a research and came to a conclusion that child labour in tourism is a very widespread phenomenon. As Hagedoorn (2013) further cites, Black (1995) traced the historical trend of child labour utilization in the world tourism industry. According to him 13 to 19 million children and youth under eighteen years of age are employed in the formal tourism industry worldwide. Child labour therefore counts for approximately $10 \%$ of the formal tourism labour market. Citing the research of Maplecroft (2012) Hagedoorn (2013) stated that employing of child labour in the tourism industry is more common at the world's popular tourist destinations such as the Philippines, India, China, Vietnam, Indonesia and Brazil.

The studies on child labour reviewed above indicate certain aspects of the problem. But there is a dearth of research which deals with child labour in the tourism and hospitality industry especially, which focus on the spatial issues and challenges.

In Sri Lanka too it has seen that there is a dearth of research which focuses on child labour utilization in the tourism industry. The Ministry of Labour Relations and Productivity Promotion (2010) has compiled a report on Sri Lanka's Road Map 2016 on the Worst Forms of Child Labor, under the aegis of the ILO which reveals the child labour utilization of various sectors including estate, fisheries and tourism. This study focuses on the need to understand the prevailing socioeconomic situation and advocate a closer look into the deep roots in order to reveal the nature of the children's economic contribution. As thousands of children are working in the tourism industry and facing lots of social problems like losing their social identity, child prostitution and various kinds of human disease, a need has arisen to investigate the reasons, adverse effects and seriousness of this social problem.

\section{Objective of the Study}

The main objective of this research was to study the issues and challenges of utilizing child labor in the tourism industry of the Eastern Tourism Region of Sri Lanka. The specific objectives of this research were to; examine the present nature and the structure of child labour utilization in tourism sector of this region, analyze the existing issues and challenges of child labour and recommend appropriate measures to mitigate the identified negative issues.

\section{Methodology}

The methodology of this study comprises of a number of steps; a) conducting a preliminary survey to select the study area, b) selection of the 
study area, c) conducting a pilot survey to test the questionnaires, d) data collection and e) data analysis.

\section{Selection of the Study Area}

A preliminary survey about the nature of labour utilization in the tourism industry was initially conducted to select the study area. In this regard, two tourism regions including the Colombo from the core and the Eastern from the periphery were selected. Out of the surveyed regions, it was noticed that there is a booming development of tourism in the Eastern Tourism Region. Due to this rapid development there is now an escalating demand for labour from both formal and informal sectors. But, a vacuum has been created by the scarcity of skilled human resources to cater to the increasing demand. As an alternative to this issue, child labour is being identified as a good solution by entrepreneurs involved in the industry. Thus different facets of child labour utilizing could be identified in this region. The criteria used to select the study area were the present nature of the tourism industry, the nature of utilizing child labour, the number of children employed in formal and informal employment, location of tourist attractions, location of accommodation establishments such as homestays and hotels, nature of wayside businesses and nature of tourism related informal activities. Based on these criteria, the Eastern Tourism Region in which many of the well-known tourist attractions are located, where numerous tourist hotels and homestay accommodations are concentrated and where child labour utilization is relatively high was selected to carry out the research.

\section{Selection of the Sample}

The judgment and purposive sampling methods were used to select a sample which comprised of both child workers and tourist establishments such as hotels, restaurants, homestay lodgings, recreational service centers and communications and internet cafes. Three districts viz. Ampara, Trincomalee and Batticaloa of the Eastern Tourism Region were selected as the study area. Among these districts, five main tourist attractions from each district where child labour utilization is abundant were chosen as the main sites for the detailed study. The judgment sampling technique was used to select a) the respective tourist sites and b) the hotels, restaurants, homestays and other related establishments including communications and internet cafes. Consequently, a total of 140 child workers were selected applying the purposive sampling technique. When this sample was selected, the definition of child labour cited by Hagedoorn (2013) referring the ILO was considered. Both categories of the sample were selected depending on the willingness to respond. Accordingly, the total sample selected for the survey was 190, which 
comprised of 140 child workers and 50 tourism related establishments (Table 01).

Table 01 - Distribution of the Sample

\begin{tabular}{|c|r|r|r|}
\hline District & \multicolumn{1}{|c|}{ Child Workers } & Tourism Establishments & \multicolumn{2}{|c|}{$\begin{array}{c}\text { Total Sample } \\
\text { Selected }\end{array}$} \\
\hline Ampara & 56 & 19 & 75 \\
\hline Batticaloa & 40 & 16 & 56 \\
\hline Trincomalee & 44 & 15 & 59 \\
\hline Total & $\mathbf{1 4 0}$ & $\mathbf{5 0}$ & $\mathbf{1 9 0}$ \\
\hline
\end{tabular}

Source: Field Survey, 2017-2018.

\section{Data Collection and Analysis}

The process of data collection of this study comprised of two categories, primary and secondary data collection. In order to achieve the objectives of the study, both quantitative and qualitative methods were employed to collect primary data. In this regard, questionnaire surveys, observations, interviews; both semi structured and in depth, group discussions, case studies and event records were employed. Main sources of secondary data were books, journals and other secondary sources of information related to child labour utilizing in the tourism industry. This secondary data was critically reviewed and used to write the literature review of the study.

Both qualitative and quantitative analytical methods were employed to analyze the collected data. The data collected through questionnaire survey were converted into percentages and collated in the form of tables, graphs and figures to make the data analyses and to make the presentation meaningful. As quantitative analytical tools, simple statistical methods such as central tendency (mean, medium and mode) were employed. Among the applied qualitative analytical methods, ranking and summarizing the information, making list of important facts and drawing visual displays are most prominent.

\section{Results and Discussion}

The spatial issues and challenges of child labour utilization in the tourism industry of the Eastern Tourism Region of Sri Lanka could be discussed and analyzed under several sub headings such as a) the background of child workers along with the existing nature and types of work, b) the different reasons and purposes that impact on the selection of an employment linked to tourism, c) the place of work, d) salaries and wages and the nature of expenditure of the income, e) different problems faced by child workers and f) the existing issues and challenges of child labour usage of the study area. When these multiple sectors are critically examined, spatial issues and challenges of child labour utilization in the tourism industry of the study area can be clearly analyzed. 


\section{The Background of Child Workers and the Existing Nature of Child Labour Utilization}

The background of the child workers and the existing nature of child labour utilization of the study area can be described under several headings. When the background of child workers is taken into consideration, a few dimensions were discernible.

Age is the most important characteristic in understanding all related facets of employing child labour in a particular area. As revealed by the field survey, a majority of the children (117) were below the age of 17 . There were only 23 who belonged to the age of 18 years who are almost to become elders and two (02) were below 15 years. The number of child workers who were in the age group between 15 to 17 years was 115 which is $82.1 \%$ of the total number of child workers surveyed. Therefore a conclusion can be drawn that, the majority of the child workers in the Eastern Tourism Region belong to the age group between 15 to 17 years (Table 02).

Table 02 - Number of Child Workers According to Age Limit

\begin{tabular}{|c|r|r|r|r|}
\hline Age & Ampara & Batticaloa & Trincomalee & Total \\
\hline 18 & 12 & 07 & 04 & 23 \\
\hline 17 & 21 & 19 & 18 & 58 \\
\hline 16 & 16 & 11 & 16 & 43 \\
\hline 15 & 06 & 03 & 05 & 14 \\
\hline Less than 15 & 01 & 00 & 01 & 02 \\
\hline Total & $\mathbf{5 6}$ & $\mathbf{4 0}$ & $\mathbf{4 4}$ & $\mathbf{1 4 0}$ \\
\hline \multicolumn{5}{|c}{ Source: Field Survey, 2017-2018. } \\
\end{tabular}

In a detail analysis about the spatial distribution of this facet, a few noticeable facts could be identified. Of all the research sites of the Eastern Tourism Region, the highest number of child workers belonged to the age of 17, spread out follows district wise, Ampara (21), Batticaloa (19) and Trincomalee (18). The numbers of child works belonging to the age group of 16 in each district are 16, 11 and 11 respectively. The lowest number of child workers (02) belonging to the age group of 15 or less.

According to the gender composition, it was reported that the least number (02) of female child workers was from the Trincomalee district. They have been engaged to work on the staff of communications and internet cafes. There were no females reported from Ampara and Batticaloa districts. This situation has been created by a cultural norm. Tamil and Muslim communities are the prominent nationalities of all the selected research sites. Due to this reason, females either are not permitted to work or hesitate to work in a field such as tourism. As revealed by the field survey (2017-2018), the respondents belonged to three nationalities viz. Sinhala, Muslim and Tamil (total of 140). Tamil (42.1\%) outnumbered Sinhala (23.6\%) and Muslim (34.3\%). 
The educational background of the respondents is another important criterion which should be taken into consideration in the analysis of child labour utilization. Figure 01 indicates the level of education of the child workers engage in the tourism related employment of the study area.

Figure 01 - The Level of Education of the Child Workers

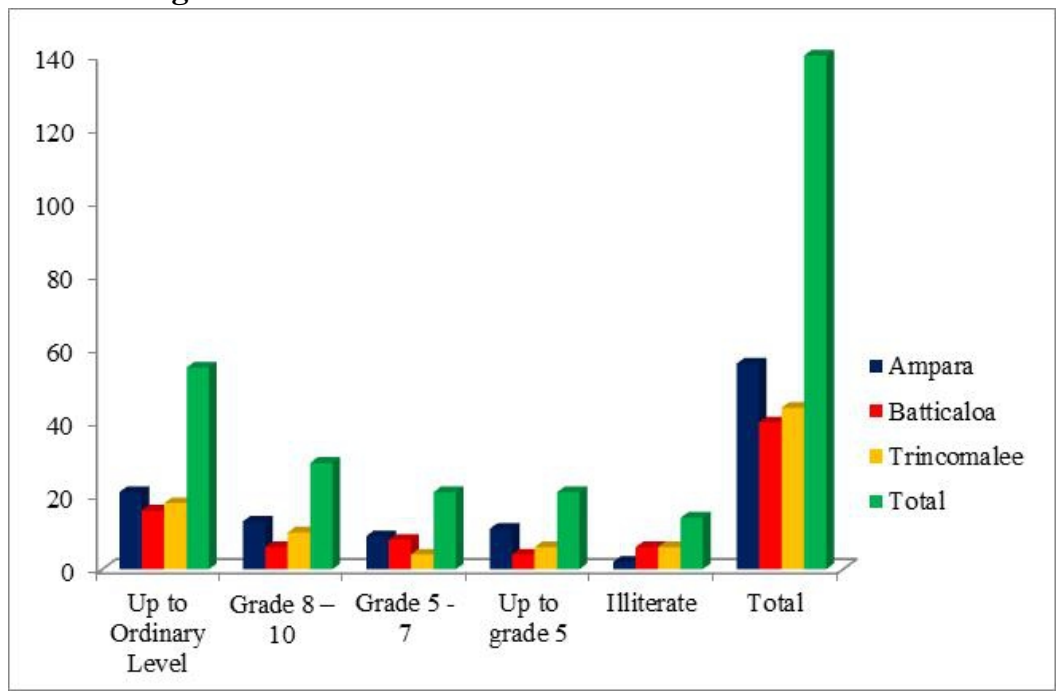

Source: Field Survey, 2017-2018.

As indicated in Figure 01, the highest number of child workers (55) in all three districts had studied up to the G.C.E Ordinary Level. That is a common facet in all three districts. In the Ampara, Batticaola and Trincomalle districts there are 21, 16 and 18 children who have studied up to this level respectively. Compared to other two districts, in Batticaloa, the number of child workers who have studied up to the level of grade 08 to 10 is much lower (06) than the other categories. Of all the districts, the number of child workers who have studied up to the level of grade 05 to 07 is 21 . A similar amount has studied up to grade 05 . When the number of respondents who are illiterate is considered, in Ampara there were 02 and Batticaloa and Trincomalle 06 by each making a total of 12 . Thus the total number of child workers who are illiterate is 14 .

Child workers of the study area are being employed in a wide variety of employment. For a detail analysis, these different employments were categorized into few categories such as hotel sector employments, assistants in different tourism related activities, tourism sector employments, janitorial/sanitary sector employments, selling or vending and other informal employments (Table 03). Hotel sector employments include; unskilled labourers in hotel construction sites, baggage carriers, bellboys and brokers for accommodation suppliers. Employments in tourism related activities 
include assistants in tourist vehicles, tourist vehicle repairers or hirers, helpers of recreational activities and watchers of tourist attractions and vehicle parks. And also sellers of agricultural products and processers and sellers of way side food stalls are employment related to selling or vending. All the employment including janitors of accommodation establishments, janitors and sanitary labours of sanitary complexes and beach cleaners have been included in the janitorial and sanitary sector employment. Not included in the above are those employed in manning communication centers and internet cafes which serve tourists who are their clientele.

Table 03 - Categories of Employment of Child Workers

\begin{tabular}{|l|r|r|r|r|r|r|r|c|}
\hline $\begin{array}{l}\text { Category of } \\
\text { Employment }\end{array}$ & \multicolumn{2}{|c|}{ Ampara } & \multicolumn{2}{c|}{ Batticaloa } & \multicolumn{2}{c|}{ Trincomalle } & \multicolumn{2}{c|}{$\begin{array}{l}\text { Total of all } \\
\text { districts }\end{array}$} \\
\cline { 2 - 10 } & Number & \multicolumn{1}{c|}{$\%$} & Number & \multicolumn{1}{c|}{$\%$} & Number & \multicolumn{1}{c|}{$\%$} & Number & \% \\
\hline $\begin{array}{l}\text { Hotel sector } \\
\text { employments }\end{array}$ & 8 & 14.3 & 04 & 10 & 05 & 11.4 & 17 & 12.1 \\
\hline $\begin{array}{l}\text { Assistants in } \\
\text { tourism related } \\
\text { activities }\end{array}$ & 10 & 17.9 & 06 & 15 & 03 & 6.8 & 19 & 13.6 \\
\hline $\begin{array}{l}\text { Tourism sector } \\
\text { employments }\end{array}$ & 10 & 17.9 & 03 & 7.5 & 03 & 6.8 & 16 & 11.4 \\
\hline $\begin{array}{l}\text { Janitorial/sanitary } \\
\text { sector }\end{array}$ & 14 & 25.0 & 12 & 30 & 15 & 34.1 & 41 & 29.3 \\
\hline $\begin{array}{l}\text { Selling } \\
\text { vending }\end{array}$ & 10 & 17.9 & 12 & 30 & 11 & 25.0 & 33 & 23.6 \\
\hline $\begin{array}{l}\text { Other informal } \\
\text { works }\end{array}$ & 04 & 7.1 & 03 & 7.5 & 07 & 15.9 & 14 & 10.0 \\
\hline Total & $\mathbf{5 6}$ & $\mathbf{1 0 0 . 0}$ & $\mathbf{4 0}$ & $\mathbf{1 0 0}$ & $\mathbf{4 4}$ & $\mathbf{1 0 0 . 0}$ & $\mathbf{1 4 0}$ & $\mathbf{1 0 0 . 0}$ \\
\hline
\end{tabular}

Source: Field Survey, 2017-2018.

Table 03 reveals that 41 child workers (out of the total 140) of all three districts of the study area are being employed in the janitorial or sanitary sector. It is the highest amount of the total tourism related employment in which the children have been employed. When the percentage wise contribution of this section is considered, it is $29.3 \%$ of the total child labour employment of the study area. The district wise spatial distribution of child labour employed is taken into account, janitorial or sanitary sector of all three districts report the highest values viz. 14, 12 and 15 child workers in the Ampara, Batticaloa and Trincomalee districts respectively. Selling or vending of different items such food, agricultural produces, votive items and fancy goods takes place the second highest place which accounts for 10,12 and 11 of each district of the study area. Total number of hotel and tourism related employment of three districts is $16(11.4 \%)$ and $17(12.1 \%)$. A large majority (13.6\%) of the child workers are employed as assistants in different tourism related activities such as assistants of tourist vehicles and tourist vehicle 
repairing or hiring centers. When the district level data is further analyzed in detail, clear spatial variations are discernible. These variations can be elaborated with a few examples. Employing of children in tourism related employment is more common and high in the Ampara district. Out of the total child workers (56) of the Ampara district 17.9\% (10) work in this sector. But it is not a prominent sector in other two districts. The percentage contributions to the tourism related employments of the Batticaloa and Trincomalle districts are $7.5 \%$ and $6.8 \%$ respectively. Another important variation in the child labour employment of the study area is that the Trincomalle district reports the lowest percentage (6.8\%) of children who are engaged as assistants in different tourism related activities.

When the employment opportunities and the sources of income of the child workers are taken into consideration, it is important to inquire about the economic status of them. The usual monthly income levels of these child workers vary between Rs. 3,000 (less than) to 15,000 (17 to 83 US\$). The details related to the level of their income are shown in Figure 2.

Figure 2 - Monthly Income Levels of the Child Workers

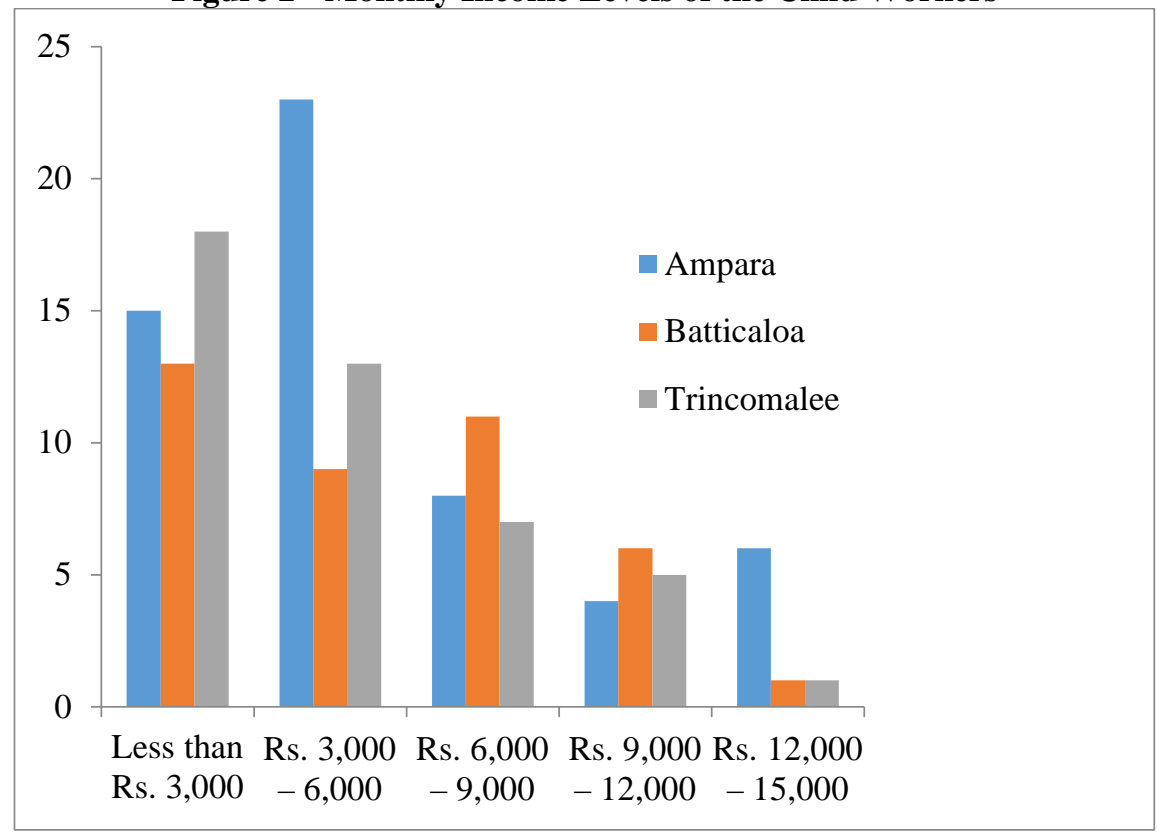

Source: Field Survey 2017-2018.

As depicted in Figure 02, only 08 child workers of all three districts have been abled to earn between Rs. 12,000 to 15,000 (66 to 83 US\$) as their monthly income. Out of which 06 child workers who have been employed in different tourism related activities of the Amapra district belonged to this income category. Other two districts reported a single child each in this income group. They are the employees in hotels and accommodation sector and staff 
of communication centers and internet cafes. Out of the total (140) child workers, 46 have earned less than Rs. 3,000 (17 US\$) as their monthly income which is the lowest range. The majority of them are the watchers in tourist attractions and vehicle parks, assistants in construction sites, cleaners, sanitary labourers, janitors and vendors. Of the above 46, Trincomalee reported the highest (18). The Ampara and the Batticaloa districts reported 15 and 13 respectively. Working on weekends or evening basis is the main reason for this lower level of income. Figure 02 further reveals that, there are 45 child workers who have earned Rs. 3,000 to 6,000 (17 to 33 US\$) per month. When the different levels of income of these child workers are taken into consideration, it is clearly evident that the individual income of number of a child worker increases relative to a higher level of education. The total number of child workers who earned a monthly income ranging from Rs. 9,000 to 12,000 (50 to 66 US\$) is 15 . The small scale dealers such as sellers of agricultural produces, items of religious importance and processers and sellers of way side food stalls are included in this income range.

When the utilization of child labour is analyzed, it is important to consider the basis of their employment such as part time, full time, evening or weekends. It was a noticeable fact that in all the districts, child workers are mainly engaged as part time workers especially on weekends, holidays and evenings. The number of children who work on a permanent basis is not significant. Out of the total child workers (140), only 16 (11.4\%) work on a full time basis while $88.6 \%$ work on a part time basis (Figure 02). As much as 24 children (42.9\%) are employed in different tourism related opportunities on weekends or on holidays, whereas $32.1 \%$ (18 children) are employed in the evening. Children who work on weekdays (08) and on a full time basis (06) had either sat for the G.C.E. Ordinary Level Examination or are school leavers. Elaborating all these, it can be concluded that a majority of child labourers of the study area work while schooling.

Figure 02 - Percentage Distribution of the Basis of Engagement in Employments of Child Workers

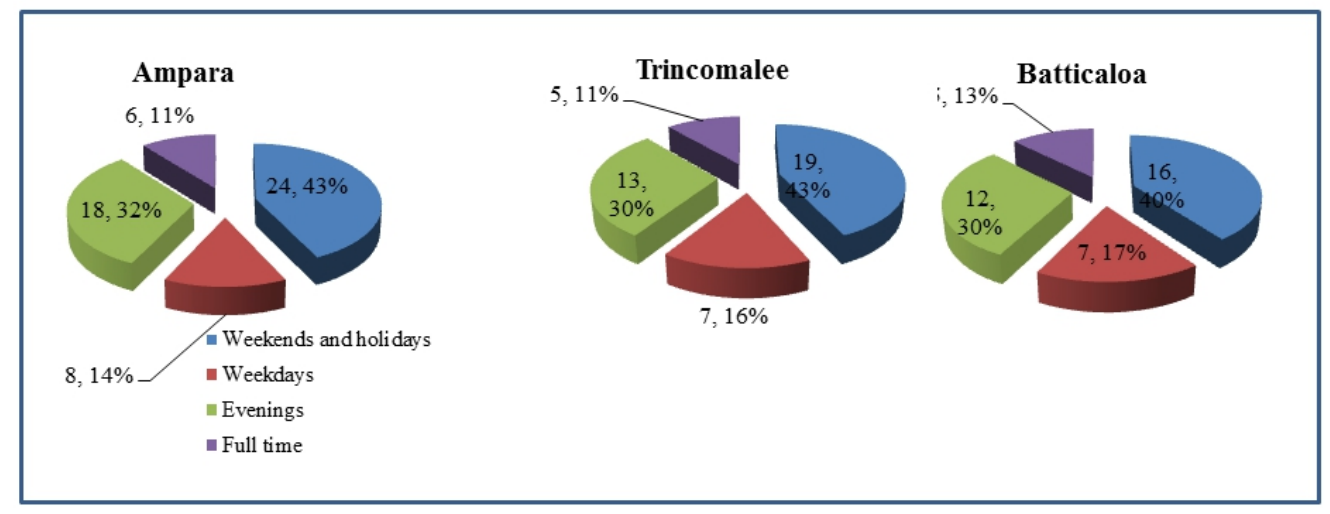

Source: Field Survey, 2017-2018. 
According to the information gathered during the field survey, different reasons have impacted on the selection of an employment linked to tourism. Among the reasons which have impacted this choice of employment are the economic burdens and domestic hardships, pressure from the parents, personal decisions such as readiness to find a job, influence made by friends and peers to join the tourism industry were prominent. These reasons have statistically been described in Table 04 .

Table 04 - Reasons Impact on the Selection of an Employment Linked to Tourism

\begin{tabular}{|l|r|r|r|r|}
\hline \multicolumn{1}{|c|}{ Reason } & \multicolumn{1}{|c|}{ Ampara } & \multicolumn{1}{c|}{ Batticaloa } & \multicolumn{1}{c|}{ Trincomalee } & \multicolumn{1}{c|}{ Total } \\
\hline $\begin{array}{l}\text { The economic burdens and } \\
\text { domestic hardships }\end{array}$ & 11 & 05 & 08 & 24 \\
\hline Pressure from the parents & 07 & 04 & 07 & 18 \\
\hline Readiness to find a job & 14 & 12 & 09 & 35 \\
\hline $\begin{array}{l}\text { Willingness to engage in } \\
\text { the family business }\end{array}$ & 05 & 03 & 05 & 13 \\
\hline $\begin{array}{l}\text { Influence of friends and } \\
\text { peers }\end{array}$ & 04 & 05 & 04 & 13 \\
\hline $\begin{array}{l}\text { Need to earn money for } \\
\text { personal use }\end{array}$ & 08 & 07 & 06 & 21 \\
\hline Other Total & 07 & 04 & 05 & 16 \\
\hline \multicolumn{1}{|c|}{} & $\mathbf{5 6}$ & $\mathbf{4 0}$ & $\mathbf{4 4}$ & $\mathbf{1 4 0}$ \\
\hline
\end{tabular}

Source: Field Survey, 2017-2018.

As showing in Table 04, a total of 35 child workers (12, 12 and 09 from the Ampara, Batticaloa and Trincomalee districts respectively) decided to work in a tourism related establishment due to the readiness to find a job. This is the most prominent reason. A large majority (24) have selected tourism related employment due to the economic burdens and domestic hardships. Almost 21 have been motivated by the reasons such as need to earn money for their personal use. In addition, 13 child workers had decided to work in this field due the reasons such as joining the family business and influence made by friends and peers. It was also noticed that, 16 child workers have been motivated by other reasons such as the lucrativeness of the tourism industry, the chance which they got to mingle with tourists etc. When these reasons are spatially analyzed, a few significant conclusions can be drawn. In all the districts the most prominent reason which made the highest number of child workers to select a job in tourism is their readiness to join the industry. When the order of different motives which impact on the selection of an employment related to tourism is concerned, many similarities could be noticed in every district. For example, willingness to join the industry is the main motive in all the districts. The second motivation reported from all the districts is the economic burdens and domestic hardships. 
Child workers of the study area spend the income earned from tourism related employments on different ways. As depicted in Figure 03, a total of 58 (41.4\%) spend their income to buy the daily needs of the family. This total amount is made up of 26, 14 and 18 by the child workers of the Ampara, Batticaloa and Trincomalee districts respectively. As much as $24.28 \%$ (34) of the child workers spend their income mainly to purchase books and stationery for their education. A total of 32 (22.8\%) child workers of all districts contribute to augment the family income and increase the ability of the family to renovate their existing house, to purchase household items and electrical items including televisions, refrigerators etc. or mobile phones for their personal use. Only 09 of the total children surveyed save part of their income for future use. The number of child workers who spend their earnings on pleasure activities such as watching of musical shows, attending carnivals, going on excursions and tours etc. is 07.

Figure 03 - Nature and Purposes of Expenditure

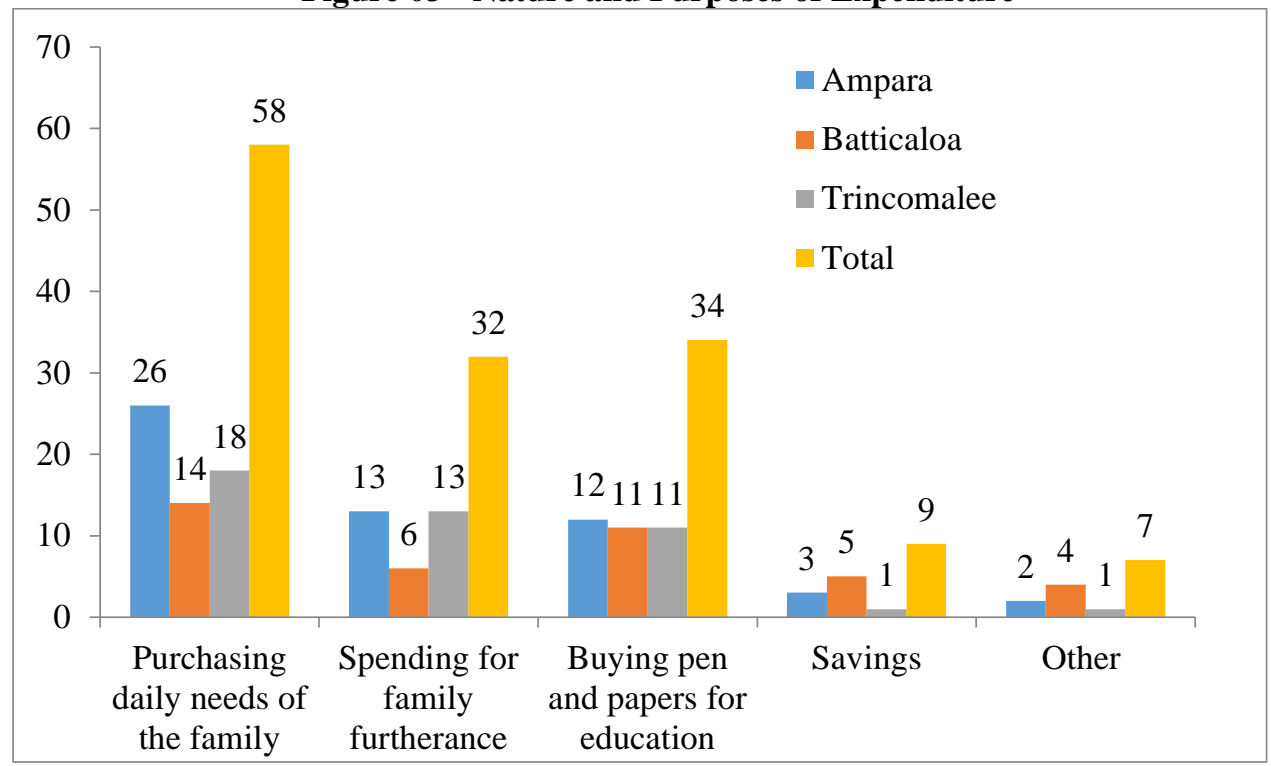

Source: Field Survey, 2017-2018.

When the districts level information of Figure 03 is further analyzed, many differences at districts level can be noticed. Even though the highest number of child workers (26, 14 and 18 in Ampara, Batticaloa and Trincomalee respectively) mainly spend their income to purchase daily needs for the family, there are differences when the other nature of expenditures are taken into consideration. In the Ampara district, out of the total of 56 child workers, 13 spent the income earned from tourism for their family furtherance. This nature is common in the Trincomalee district too. But the second main expenditure of the child workers of the Batticaloa district is to buy books and stationery for their education. Considerable percentages of child workers of 
the Ampara and Batticaloa districts (5.3\% and 12.5\% respectively) allocate a share of their income for savings. But all most all of the child workers of the Trincomalle district save one do not save any money. A similar trend can be noticed when all other forms of expenditure too are concerned.

\section{Issues and Challenges of Utilizing Child Labour in the Tourism Industry of the Study Area}

Even though tourism related employments of the study area have contributed to the betterment of the children and their families in different ways, many issues and challenges could be observed. Owing to different reasons, children of the Eastern Tourism Region who have been employed in different tourism related employment faced several difficulties and problems. Concurrently, the tourism related establishments including hotels, homestays, restaurants and communication centers and internet cafes experience different issues. Not only them, other owners and operators of informal businesses connected to this industry in the study area too faced similar difficulties though of different dimensions. These formal and informal business communities include; the operators and owners of recreational services, transport providers both formal and informal, wayside vendors, private owners of vehicle parks and small scale business communities who own small cafes, shops etc.

When studying this from an overall perspective, the above issues and challenges related to the child labour utilization in the tourism industry of the study area can be classified into two categories viz. the issues faced by the child workers and the issues faced by the business community both formal and informal.

\section{The Problems Faced by the Child Workers of the Eastern Tourism Region}

Employing children in any manual work is against the labour laws of the country. This has created many disadvantages to the child workers of the study area. Therefore, they work with a fear of being discovered by the law enforcing authorities and being chastised. This situation is used by their employers as an advantage to pay lower salaries and wages and without further any contribution to Employee Provident Fund and Employee Trust Fund (EPF and ETF). As a result, the child workers are not paid a fair salary. Sometimes, they have to work long hours may be for as much as 10 to 12 hours for their daily pay. On the other hand, they work in insecure working environments where they are vulnerable to exploitation even physically, mentally and sexually. As revealed by the case studies there is a risk of them being exposed to drugs and alcohol too. However, the different problems faced by these children workers could be categorized as problems related to the a) salaries and wages, b) long working hours, c) risk in jobs, d) heavy workload, e) 
harassments by superiors, f), unsafe or unhealthy working environment g) no contribution to EPF or ETF, i) absence of welfare and $\mathrm{j}$ ) other related issues (Table 5). Even though these problematic issues are common to all child workers of the study area, the extent and nature differ from district to district. This situation can be clearly analyzed when the district level data are separately taken.

Table 05 - Problems Faced by the Child Workers of Ampara District

\begin{tabular}{|c|c|r|}
\hline Rank & Problem & Number (out of 56)* \\
\hline 01. & Problems related to salaries and wages & 56 \\
\hline 02. & Long working hours & 47 \\
\hline 03. & Risk in job & 32 \\
\hline 04. & Heavy workload & 30 \\
\hline 05. & Harassments by superiors & 21 \\
\hline 06. & Unsafe /unhealthy working environment & 14 \\
\hline 07. & No contribution to EPF or ETD & 11 \\
\hline 08. & Absence of welfare & 08 \\
\hline 09. & Other (language barriers, cultural norms) & 06 \\
\hline
\end{tabular}

* Problems have been ranked into the prioritized order

Source: Field Survey, 2017-2018.

As indicated in Table 05, almost all (56) the child workers of the Ampara district are not paid properly when the working hours and the nature of the work is taken into consideration. Out of the total 56 child workers here, 47 have faced difficulties related to long working hours. As much as 32 face different risks in their jobs while 21 child workers are being harassed by their superiors. As they reported, these harassments may either be physical or mental. Similarly, 14 children have faced difficulties related to unsafe or unhealthy working environment. As ravel by the field survey, majority of the child workers do not have a definite idea about EPF or ETF. As a result, there is a very low number (11) who reported it as an issue. Since a majority of the child workers work on a part time or evening basis, they have little or no welfare activities. Eight (08) child workers have faced this difficulty. In addition, there are other related issues which they face occasionally. Influence of tourists or the adult permanent employees to use alcohol or to smoke, vulnerability to exploitation, sexual harassments and delay in payments are some of the issues which they mentioned under this category.

The child workers of the Batticaloa district too face similar problems but the ranking is different (Table 06). 
Table 06 - Problems Faced by the Child Workers of Batticaloa District

\begin{tabular}{|c|c|c|}
\hline Rank & Problem & Number (out of 40)* \\
\hline 01. & Heavy workload & 34 \\
\hline 02. & Problems related to salaries and wages & 31 \\
\hline 03. & Long working hours & 21 \\
\hline 04. & Risk in job (risk of exposure to smoking etc.) & 12 \\
\hline 05. & Unsafe /unhealthy working environment & 11 \\
\hline 06. & Harassments by superiors & 07 \\
\hline 07. & No contribution to EPF or ETD & 05 \\
\hline 08. & Absence of welfare & 02 \\
\hline 09. & Other (language barriers, cultural norms) & 02 \\
\hline
\end{tabular}

* Problems have been ranked into the prioritized order Source: Field Survey, 2017-2018.

As shown in Table 06, there are several noticeable issues faced by the child workers of the Batticaloa district. The top ranked problematic issue has been created due to the heavy workloads. Out of the total 40 children, 34 have ranked this as the main issue. Long working hours is another problem for 21 child workers while 12 have faced difficulties due to risky nature of jobs. Accordingly, the number of child workers who work under unhealthy working environments is 10. Number of individuals who face other difficulties such as EPF or ETF issues, less welfare in the job and other related issues are least important.

When the problems faced by the child labourers of the Trincomalee district are analyzed, several noticeable factors are discernible (Table 07).

Table 07 - Problems Faced by the Child Workers of Trincomalee District

\begin{tabular}{|c|c|r|}
\hline Rank & Problem & \multicolumn{1}{|c|}{ Number (out of 44)* } \\
\hline 01. & Problems related to salaries and wages & 40 \\
\hline 02. & Heavy workload & 34 \\
\hline 03. & Long working hours & 18 \\
\hline 04. & Risk in job (risk of exposure to smoking etc.) & 15 \\
\hline 05. & Unsafe /unhealthy working environment & 11 \\
\hline 06. & Harassments by superiors & 02 \\
\hline 07. & No contribution to EPF or ETD & 02 \\
\hline 08. & Absence of welfare & 02 \\
\hline 09. & Other (language barriers, cultural norms) & 01 \\
\hline
\end{tabular}

* Problems have been ranked into the prioritized order

Source: Field Survey, 2017-2018.

Similarly in the Ampara district, the prominent problem of the Trincomalee district too is the issues related to less payment of wages and the number of children who faced this issue is 40 . As much as 34 child workers 
have faced different difficulties related to the heavy workload. The number of child workers who work under unhealthy working environment is 11 . Other problems such as harassments by superiors, absence of welfare in the jobs and other related problems that are faced by the children in the tourism industry of this district are insignificant and only 02 respondents have stated that hardly they have to face such difficulties.

Based on the percentage distribution, the issues and challenges faced by the child workers of the study area can be analyzed more critically. When the spatial distribution of the total number of child workers is considered, many noticeable features are discernible (Table 08).

Table 08 - Percentage Distribution of Issues and Challenges Faced by the Child Workers

\begin{tabular}{|c|c|c|c|c|c|c|}
\hline Problem & $\begin{array}{c}\text { Ampara* } \\
\text { (Out of } \\
\mathbf{5 6 )}\end{array}$ & $\mathbf{\% *}$ & $\begin{array}{c}\text { Batticaloa } \\
\text { (Out of } \\
\mathbf{4 0 )}\end{array}$ & $\mathbf{\% *}$ & Trincomalee & \%* \\
\hline $\begin{array}{c}\text { Problems related to } \\
\text { salaries and wages }\end{array}$ & 56 & 100 & 31 & 77.5 & 40 & 90.9 \\
\hline Long working hours & 47 & 83.9 & 21 & 52.5 & 18 & 40.9 \\
\hline Risk in job & 32 & 57.14 & 12 & 30 & 15 & 34 \\
\hline Heavy workload & 30 & 53.5 & 34 & 85 & 34 & 77.2 \\
\hline $\begin{array}{c}\text { Harassments by } \\
\text { superiors }\end{array}$ & 21 & 37.5 & 7 & 17.5 & 2 & 4.5 \\
\hline $\begin{array}{c}\text { Unsafe /unhealthy } \\
\text { working environment }\end{array}$ & 14 & 25 & 11 & 27.5 & 11 & 25 \\
\hline $\begin{array}{c}\text { No contribution to } \\
\text { EPF or ETD }\end{array}$ & 11 & 19.64 & 5 & 12.5 & 2 & 4.5 \\
\hline Absence of welfare & 8 & 14.2 & 21 & 52.5 & 2 & 4.5 \\
\hline Other & 6 & 10.7 & 2 & 5 & 1 & 2.2 \\
\hline
\end{tabular}

* Percentages have been calculated based on the total number of respondents of each district Source: Field Survey, 2017-2018

When the percentage wise distribution of the problems and issues faced by the child workers are taken into account, 100 percent of the child workers i.e. the whole sample of the Ampara district do not receive proper payments. As opposed to this, all most all children who work in the tourism sector of other two districts do not face this difficulty. The relevant percentage values of the Batticaloa and Trincomalee districts in this regard are $77.5 \%$ and $90.9 \%$ which is also a large majority. Almost $83.9 \%$ of the Ampara district severely faces the issue of long working hours. But only 52.5\% and $40.9 \%$ child workers (nearly a half of the sample) of the Batticaloa and Trincomalee districts face this problem. The most problematic issue of these two districts is the heavy work load which has to be completed during their working hours. The percentage values of these issues are $85 \%$ and $77.2 \%$. A significant proportion i.e. 53.5\% of child workers of the Ampara district faces this difficulty. When the other issues such as harassments by superiors, unsafe or 
unhealthy working environment, nonpayment of EPF or ETF, absence of welfare in the job and other related issues too are analyzed, spatial variations are clearly discernible.

\section{Problems Faced by the Business Community}

As discussed above, there are many issues and challenges faced by the child workers of the three districts of the study area. Due to different reasons, the business community of the study area too has faced several difficulties and problems when children are employed in different employment. As revealed by the different interviews and group discussions conducted with the tourism related business community of the study area, there are several issues related to the overall labour utilization (child and adult). Among them, following are noteworthy. Most of the tourism related employment of the Eastern Tourism Region are temporary and casual. People who engage in different jobs have been recruited only for a four to five month period which is the peak season of the tourism industry of the region. Due to this nature of employment and the tourism industry of the region, they receive fringe benefits along with comparatively low tips and service charges. Ultimately, their take home salary is very low. This results in a fluctuation between the high and low season. On the other hand they do not receive a fix income instead a fluctuated. Due all these reasons, skilled and educated employees are reluctant to continue in tourism related jobs in this region. This has created a vacuum and a scarcity in the labour market in the tourism sector of the Eastern Tourism Region. To fill this vacuum, the business community of this region has identified child labour as an option. But employing children is against the labour law of the country. As a result of that, they have no legal permit to employing children in their businesses. As reveled by the field survey, the common issues and challenges faced by the business community in the study area can be summarized as shown in Table 09.

Table 09 - Common Issues and Challenges Faced by the Business Community

\begin{tabular}{|c|r|r|r|}
\hline Issue & $\begin{array}{c}\text { Ampara } \\
\text { (out of 19) }\end{array}$ & $\begin{array}{c}\text { Batticaloa } \\
\text { (out of 16) }\end{array}$ & $\begin{array}{c}\text { Trincomalee } \\
\text { (out of 15) }\end{array}$ \\
\hline Poor attendance & 18 & 14 & 13 \\
\hline Carelessness & 14 & 09 & 11 \\
\hline No responsibility on the work & 17 & 11 & 00 \\
\hline $\begin{array}{c}\text { Unnecessary connections with } \\
\text { guests }\end{array}$ & 04 & 01 & 13 \\
\hline Demand of high salaries & 17 & 14 & 01 \\
\hline Thefts of valuable items & 02 & 01 & 09 \\
\hline Ready to work on daytime only & 12 & 07 & 06 \\
\hline Less adaptation & 11 & 10 & 13 \\
\hline Illiteracy & 17 & 14 & 13 \\
\hline Less language knowhow & 15 & 14 & \\
\hline
\end{tabular}

Source: Field Survey, 2017-2018. 
As indicated in Table 09, it is clearly apparent that poor attendance, carelessness, no responsibility on the work, demanding high salaries, ready to work on daytime only, less adaptation, illiteracy and the less language knowhow are the most noticeable issues faced by the business community. When the spatial diversity of these issues is considered, certain conclusions can be drawn. The most problematic issue faced by the business community of all three districts is poor attendance of the child workers as reported by 18 , 14 and 13 business people by the Ampara, Batticaloa and Trincomalee districts respectively.

All most all business men (17, 14 and 13 of each district) face two main issues viz. the demand of high salaries and illiteracy among the child workers. The readiness to work only during the day time too is a common issue to all the business men of the study area. Out of the total number of respondents 12 in the Ampara, 07 in the Batticaloa and 09 in the Trincomalee districts are faced with this issue. On the other hand, poor adaptability of child workers to the tasks involved is further problematic issues of the business community. Almost 11, 10 and 06 respondents of Ampara, Batticalo and Trincomalee districts district face this issue. As a result, the business community has to train the child workers over and over again which has adverse effects on the profits of their businesses. Theft of valuable items either of tourists or of the place of work is the issue which is faced by the least number of business men. Thus, these ongoing issues faced by the business community of the study area make the labour scarcity of the region a problem of notable dimension.

\section{Conclusion}

The spatial issues and challenges of child labour utilization in the tourism industry of the Eastern Tourism Region of Sri Lanka have been analyzed under two main themes.

The overall nature of the child labour utilization of the study area can be treated under several sub headings such as the background, the existing nature, types of work, the different reasons that impact on the selection of an employment and the socio economic background of child workers. The focal attention of this study was to analyze the issues and challenges of the utilization of child labour in the tourism industry of the Eastern Tourism Region. This was discussed under two main themes such as the different issues and challenges faced by child labourers and the business community of the study area. As revealed by the field survey, a large majority of the children (82.1\%) who have been employed in the tourism industry of the study area is in the age group 15 to 17 years. According to the gender composition, a least number (02) of female child workers have been engaged and that too as staff of communications and internet cafes. This situation has been created by 
cultural norms of the Tamil and Muslim communities, which form a substantial problem of the overall community. The percentage of Tamil child workers $(42.1 \%)$ of the region outnumbered Sinhala (23.6\%) and Muslim (34.3\%). The respondents of the study area belong to different levels of education. Majority of them had studied up to the G.C.E. Ordinary Level examination. The overall level of education of the child workers of the Ampara district is higher than of the other two districts. This situation can be further elaborated when the number of respondents who are illiterate is considered. Only 02 child workers of the Ampara district are illiterate and the Batticaloa and Trincomalle districts report 06 by each which ultimately accounts for a total of 14 .

Different areas of employment in which the child workers have been employed can be categorized into two categories viz. hotel sector employments and tourism related employment. A large majority (41 child labourers) of all three districts have being employed in the janitorial or sanitary sector. When the district wise spatial distribution of child labour employment is taken into account, janitorial or sanitary sector of all three districts reports highest. Employing of children in tourism related employment is more common and higher in the Ampara district. But it is not so prominent in the other two districts. When the two different employment sectors are taken into account as a whole, tourism related employment out number hotel related employments.

According the economic status of the child workers, the usual monthly income levels vary between Rs. 3,000 to 15,000. Even though there are many discrepancies in the income, the child laboures who have been employed on a full time basis receive a higher income than those who work in the evening or on a part time basis. The majority of these who receive a lower income are engaged in jobs such as the watchers at tourist attractions and vehicle parks, assistants in construction sites, cleaners, sanitary labourers, janitors and vendors. When the different levels of income of these child workers are considered, it is clearly evident that the number of child workers who earn a low income decreases when the level of income is increased. It was a noticeable fact that, in all the districts child workers are mainly engaged as part time workers especially on weekends, holidays and evenings. The number of children who work on a permanent basis is not significant. Out of the total child workers only $11.4 \%$ work on a full time basis while $88.6 \%$ work part time. The most prominent aspect in this regard is that a majority of child labourers of the study area, work while schooling. According to the field survey, different reasons have impacted on the selection of an employment linked to tourism. Among them, the economic burdens and domestic hardships, pressure from the parents, personal decisions such as readiness to find a job and influence made by friends and peers were prominent. In all the 
districts surveyed, the major reason which impacted on the selection of this field is the readiness to find a job. It was also noticed that, a large majority (24) have selected a tourism related employment due to the economic burdens or hardships at homes, need to earn money for personal use, willingness to engage in the family business and influence made by the friends and peers, the lucrative nature of the tourism industry. The opportunity to mingle with tourists is the other reason.

Child workers of the study area spend the income earned from tourism related employments in different ways. As much as $41.4 \%$ spend their income to buy the daily needs of the family. But there are differences when the spatial data at district level is concerned. Though they spend their income for different purposes such as purchasing books and stationery for the education, contributing to the family expenses, on pleasure and entertainment activities and purchasing household items, many of them hardly save any money.

Even though tourism related employment in the study area have contributed for the economic betterment of the children and their families and the business community in different ways, many issues and challenges could be observed. These issues and challenges could be categorized into two categories viz. the issues faced by the child workers and the problems faced by the business communities.

Among the different problems faced by these child workers those related to salaries and wages, long working hours, risk involved in the work place, heavy work lords, harassments by superiors, unsafe or unhealthy working environment, no contribution to EPF or ETD, absence of welfare in the work place and other related issues are noteworthy.

Low wages is the most adverse issue among all them. When the percentage wise distribution of the problems and issues faced by the child workers are taken into account, 100 percent of the child workers (that is the whole sample of the Ampara district) do not receive proper wages. But most children who work in the tourism sector of the other two districts do not face this difficulty. A highest number of child workers of these districts too face this issue to this extent. The relevant percentage values in the Batticaloa and Trincomalee districts are as heavy as $77.5 \%$ and $90.9 \%$ which is also a large majority though not 100\%. An $83.9 \%$ of the Ampara district child workers severely face the issue of long working hours. Only 52.5\% and 40.9\% child workers of the Batticaloa and Trincomalee districts face this identical problem. One of the most problematic issues of these two districts is the heavy work load which has to be completed during their short working hours.

Even though the extent is different, the business community of the study area too has faced several difficulties related to the use of child labour in their businesses. Due to different reasons there is a dearth of skilled and educated human resource suitable for employ in the tourism establishments of 
this region. Child labour has been identified by them as a fine remedy, but has no legal permit to employing children in their business. How ever, the common issues which the business community of the study area face are the poor attendance, lack of diligence and responsibility in their work, demand for high wages, their readiness to work during the daytime only, less adaptation, illiteracy and the poor proficiency in language usage especially in English which is a sine quo non in tourist related activities, especially when dealing with foreign tourists. Among them, the most problematic issue faced by the business community of all three districts is poor attendance of the child workers. It was also noticed that, the readiness to work only in the day time too is a common issue. Theft of valuable items either of tourists or the place of work is the issue which is faced by a least number of business men. How ever the ultimate impact of all the problems above is the labour scarcity in the tourism industry of the region.

\section{References:}

1. Das, S. and Sing, A.K. (2016) "Socio Economic Condition of Child Labour Working in Hotel Industry of Barak Valley in Assam: A Study”, Pezzottaite Journals, Vol. 05 (02), Kashmir, India.

2. Hagedoorn, E. (2013) "Child Labour and Tourism; How Travel Companies Can Reduce Child Labour in Tourism Destinations", Occasional Paper 25 for the ICRT, Durham, United Kingdom.

3. International Labor Organization, (2012) Tackling Child Labour: From Commitment to Action; International Programme on the Elimination of Child Labor (IPEC), Vol. 01 (14), Geneva, Switzerland.

4. International Labour Organization, (2007) Eliminating Child Labour; Guides for Employers, Geneva, Switzerland.

5. Kanbargi, R. (1991) Child Labour in Indian Subcontinent: Dimensions and Implications, Sage Publication, New Delhi, India.

6. Kannan, R. (2007) Rescuing Child Laborers from Homes and Hotels, Retrieved from, http://www.thehindu. com/2007/10/09/stories/2007100961020400.htm.

7. Luwaga, J. (2005) Child Labour and Scholastic Retardation: A Thematic Analysis of the 1999 Survey of Activities of Young People in South Africa, MA Thesis in Demography, University of Pretoria, South Africa.

8. Ministry of Labour Relations and Productivity Promotion, (2016) Sri Lanka's Roadmap 2016 on the Worst Forms of Child Labour From Commitment to Action, Colombo, Sri Lanka.

9. Nagar, N. and Roy, B. (2016) "A Critical Analysis Of Child Labour In India”, International Journal of Current Research in Multidisciplinary, Vol. 01 (05). 
10. Rao, N. (2008) "Child Labour in the Services in India: The Case of Tourism", Paper Presented at the Seminar Enslaved Innocence, 14 March, 2008, Centre for Jawaharlal Nehru Studies, Jamia Milia Islamia.

11. Sharma, A., Kukreja, S and Sharma, A. (2012) "Child Labour - An Ugly Face of Travel and Hospitality Industry”, IOSR Journal of Business and Management, Vol. 04 (01).

12. United Nations, (2018) World Day Against Child Labour, Retrieved from, http://www.un.org/en/events/childlabourday/background.shtml. 